\title{
Effects of Tamoxifen on Premenopausal Breast Cancer Patients in Terms of Anxiety, Depression, Quality of Life and Sexual Satisfaction
}

\section{Premenapozal Meme Kanseri Hastasında Tamoksifenin Anksiyete, Depresyon, Yaşam Kalitesi ve Cinsel Doyum Üzerine Etkisi}

\author{
Ahmet Alacacıoğlu ${ }^{1}$, Eda Ülger ${ }^{1}$, Umut Varol $^{1}$, İbrahim Yıldız ${ }^{1}$, Tarık Salmann ${ }^{1}$, Vedat Bayoğlu ${ }^{1}$, Ahmet \\ Dirican $^{1}$, Murat Akyol ${ }^{1}$, Yaşar Yıldız $^{1}$, Yüksel Küçükzeybek ${ }^{1}$, İnci Alacacıoğlu ${ }^{2}$, Mustafa Oktay Tarhan ${ }^{1}$ \\ ${ }^{1}$ Izmir Katip Celebi University, Ataturk Training And Research Hospital, Department Of Medical Oncology, \\ Izmir, Turkey \\ ${ }^{2}$ Dokuz Eylul University, Faculty Of Medicine, Department Of Hematology, Izmir, Turkey
}

\section{ÖZET}

Amaç: Bu çalışmada premenapozal meme kanserli hastalarda tamoksifenin etkilerini, anksiyete, depresyon, yaşam kalitesi ve cinsel doyumları açısından belirlemek amaçlandı.

Yöntem: Adjuvan tamoksifen kullanan 67 premenapozal meme kanserli kadın çalışmaya dahil edildi ve veriler yüzyüze görüş̧me sırasında bir dizi formlar kullanılarak toplandı. Çalışmada, sosyo-demografik bilgi formu, Hastane Anksiyete ve Depresyon Ölçeği (HADS), Golombok-Rust Cinsel Doyum Ölçeği (GRCDÖ) ve Yaşam Kalitesi Ölçeği (EORTC-QoL-C30) uyguland.

Bulgular: Hastaların \%46.26'sında depresyon, \%40.29'unda yüksek seviyede anksiyete saptandı. Fiziksel, rol, bilişsel, duygusal ve sosyal işlevsellik ve global yaşam kalitesi alt skorları, anksiyete seviyeleri yüksek hastalarda düşük bulundu. Depresyon skorları yüksek olan hastalarda, fiziksel işlevsellik ve global yaşam kalitesi alt skorları dışındaki tüm işlevsellik skalaları istatistiksel olarak düşük bulundu. Anksiyete seviyeleri yüksek olan hastalarda, tüm GRCDÖ altskorları yüksekti. Fakat istatiksel olarak fark sadece iletişim, doyum, dokunma ve anorgasmi alt skorlarında gözlemlendi. Depresyon seviyeleri yüksek olan hastalarda tüm GRCDÖ alt skorları yüksekti. Fakat istatiksel olarak fark sadece iletişim, doyum, dokunma ve anorgasmi alt skorlarında gözlemlendi. Sonuç: Meme kanseri ve uzun dönemli adjuvant tedaviler, hastaların sadece klinik durumlarını değil psikososyal ve psikoseksüel durumlarını da etkilemektedir. Bu nedenle, bu durumların farkında olunması, meme kanserli hastaların yaşam kalitesini yükseltecektir.

Anahtar Kelimeler: Depresyon; Anksiyete; Yaşam kalitesi; Cinsel doyum; Meme kanseri

\begin{abstract}
Objective: In this study, we aimed to determine the effects of tamoxifen on premenopausal breast cancer patients in terms of anxiety, depression, quality of life (QoL) and sexual satisfaction.

Methods: Sixty-seven premenopausal patient with breast cancer using adjuvant tamoxifen were participated in the study and the data were collected by using a series of forms that completed during face-to-face interviews. The form that consists of socio-demographic characteristics of the pateints, the Hospital Anxiety and Depression Scale (HADS), Golombok-Rust Inventory of Sexual Satisfaction (GRISS) and European Organization for Research on Treatment of Cancer Questionnaires Quality of Life-C30 (EORTC-QoL-C30) were applied to the participants.

Results: We determined that $46.26 \%$ of the patients had depression and $40.29 \%$ had high anxiety levels. Physical, role, cognitive, emotional and social functioning and global QoL subscores were also found to be low in patients whose anxiety levels were high. In patients whose depression scores were high, all the functioning scales, except physical functioning scale and global QoL subscores of EORTC-QLQ-C30 were found statistically significantly low. All the GRISS subscores were higher in the patients whose anxiety levels were high. However, statistical significance was observed only in the communication, satisfaction, touch and anorgasmi subscores. All the GRISS subscores were higher in the patients who had high depression level. But the statistical significance was found only in communication, satisfaction, touch and anorgasmi subscores. Conclusion: Breast cancer and its long-term adjuvant treatments affect not only the patients' clinical status but also their psychosocial and psychosexual aspects. Therefore, being aware of these aspects and management of them may increase the quality of life of breast cancer patients.
\end{abstract}

Key words: Depression; Anxiety; Sexual satisfaction; Quality of life; Breast cancer 


\section{Introduction}

Breast cancer (BC) is the second most common cancer and the second leading cause of cancer deaths in women (1). Treatment of breast cancer contains three main modalities; surgery, radiotherapy and chemotherapy (2). Besides, hormonal therapy has also an important role in the treatment of breast cancer. Among the hormonal agents, tamoxifen is the most commonly used drug in the premenopausal setting. Tamoxifen can be administered as adjuvant, neoadjuvant or palliative intent.

Although breast cancer patients have high survival rate mainly because of the developments in medical technology and understanding its tumor biology, treatmentrelated side effects may still lead to physical and psychological distress in the breast cancer survivals $(3,4)$. In one of the study, psychiatric disorders were observed in about half (47\%) of the cancer patients (5). Depression and anxiety in cancer patients were also estimated ranging from $1.5 \%$ to $50 \%$ and from $20 \%$ to $50 \%$, respectively $(6,7)$. Depression and anxiety rates are highly correlated in women with $\mathrm{BC}$ and most of them suffer from both types of symptoms (8). Breast cancer patients with depression and anxiety often increase physical side effects and may experience reduced quality of live (QoL) (9). Additionally, many studies showed that there was a significant correlation between sexual problems and reduced QoL among younger BC survivors $(10,11)$. Moreover, these negative mood states significantly increase the risk of mortality in women with BC (12).

Tamoxifen, an anti-estrogenic agent, improves survival of premenopausal earlystage breast cancer female patients. It often results in menopausal symptoms, permanent infertility or the need to delay pregnancy (1315). However, it is still unclear whether tamoxifen has a positive or adverse effect on sexual functioning $(16,17)$. In a related study with limited number of patients, it is reveald that treatment with tamoxifen may not lead to contribute sexual problems (18). On the contrary, when vaginal smears were obtained before and after tamoxifen treatment, it is found that this drug has estrogen agonist effect on vaginal mucosa (19). So, treatment with tamoxifen may cause vaginal atrophy and problems with sexual desire.

Especially in recent years, despite the increase in the number of studies examining the psychosocial and psychosexual changes in the women diagnosed with breast cancer, there are few studies that investigated the effects of tamoxifen with respect to these aspects. So, we aimed to evaluate the effects of adjuvant tamoxifen treatment on anxiety, depression, QoL and sexual satisfaction of the premenopausal breast cancer patients.

\section{Materials and Methods}

\section{Patient Selection}

Sixty-seven premenopausal breast cancer patients treated with adjuvant tamoxifen in medical oncology clinics of Izmir Katip Celebi University Atatürk Research and Training Hospital were enrolled in this study. Breast cancer patients who did not have a partner were excluded. Seventy-one eligible women with breast cancer were asked to participate in the study and four of them denied answering the questionnaires. So, 67 patients were selected for this study.

\section{Data collection}

The data were collected using a series of forms completed during face-to-face interviews by trained interviewers for determination of the psychological status, sexual satisfaction, and quality of life of the patients. The participants were informed about the study. Informed consent was applied and no interview was conducted without the written consent of the patient. Participants were asked to complete four questionairres. The first form consisted of questions regarding the socio-demographic characteristics and medical history of the patients.

The second form was the Hospital Anxiety and Depression Scale (HADS) The Hospital Anxiety and Depression Scale is a self-assessment scale that has been developed and found to be a reliable instrument for detecting states of depression and anxiety in the setting of a hospital medical outpatient clinic. It is suggested that the introduction of HADS into general hospital practice would facilitate the large task of detection and 
management of emotional disorder in patients under investigation and treatment in medical and surgical departments. This scale is made up of 14 items consisting of HADS-A (Anxiety, 7 questions) and HADS-D (Depression, 7 questions) subscales (20). Each item on the questionnaire is scored from 0-3 and this means that a person can score between 0 and 21 for either anxiety or depression and an overall total score ranging from 0 to 42 with higher scores indicating greater levels of depression and anxiety. The HADS was translated in to Turkish by Aydemir O. et al (21). After satisfied validity and reliability studies, it was reported as a suitable tool for the Turkish population. The reliability coefficient of the anxiety and depression HADS subscales for the Turkish patient group was 0.85 and 0.78 , respectively (21).

The third form was the Golombok-Rust Inventory of Sexual Satisfaction (GRISS). The Golombok-Rust Inventory of Sexual Satisfaction (22) is a 28-item questionnaire used to evaluate the quality of the sexual life and sexual dysfunction. It has two different types for males and females. The female form includes 7 subscales as frequency, communication, satisfaction, avoidance, touch, vaginismus and anorgasmi. The male form includes impotence and premature ejaculation instead of anorgasmi and vaginismus. A score of 5 points or higher in any category reveals sexual dysfunction. A validation and reliability study of GRISS in Turkish population was done by Tugrul C. et al (23). In our study we used only the female form.

The fourth form was European Organization for Research on Treatment of Cancer Questionnaires Quality of Life-C3O (EORTC-QOL-C30): The EORTC QOL-C30 is a questionnaire developed to assess the quality of life of cancer patients. It consists of 30 items that measure the quality of life of cancer patients into three major domains: functional scales, global health/quality of life and symptom scales (24). Functional scales consist of physical (five items), social (two items), emotional (four items), role (two items) and cognitive (two items) items. Quality of Life scale consists of two items. There are also nine symptom scales associated with fatigue (three items), nause and vomiting (two items), pain (two items), dyspnea, insomnia, appetite loss, diarrhea and constipation (one each items) (25). A validation and reliability study of EORTC-QOL-C30 in Turkish population was done by Beser and $\mathrm{Oz}$ (26).

\section{Statistical analysis}

All data were analyzed by using SPSS for Windows version 20.0. Descriptive statistics summarized frequencies and percentages for categorical variables, mean and standard deviation for continuous variables. Independent samples T-tests were used to compare categorical variables. A value of $\mathrm{p}<0.05$ was considered as significant.

\section{Results}

The mean age of breast cancer patients was $42.7 \pm 4.7$ (range, 34-50). Among the patients, local disease (44.8\%) and locally advanced disease $(55.2 \%)$ was nearly equally distributed. Most of the patients (71.6\%) had primary education while only $6 \%$ of them were graduated from university. Thirty-seven patients $(55.2 \%)$ had cancer history in their families. The demographic and clinical characteristics of the 67 female breast cancer patients were shown in Table 1 .

Table 1. Demographic and clinical characteristics of the patients

\begin{tabular}{lc}
\hline $\begin{array}{c}\text { Demographic and Clinical } \\
\text { Characteristics }\end{array}$ & $\begin{array}{c}\text { Patients } \\
(\mathbf{n = 6 7})\end{array}$ \\
\hline Age (mean \pm SS) (min-max) & $42.7 \pm 4.7(34-50)$ \\
\hline Education & $48(71.6 \%)$ \\
Primary Education & $15(22.4 \%)$ \\
High School & $4(6 \%)$ \\
University & $29(43.3 \%)$ \\
\hline Monthly income & $38(56.7 \%)$ \\
$\quad<1000$ TL & \\
$\geq 1000$ TL & $37(55.2 \%)$ \\
\hline Cancer History of Family & $30(44.8 \%)$ \\
$\quad$ Yes & \\
No & $30(44.8 \%)$ \\
\hline Type of Surgery & $37(55.2 \%)$ \\
Modify Radical Mastectomy & \\
Breast Conservation Surgery & $30(44.8 \%)$ \\
\hline Disease Stage & $37(55.2 \%)$ \\
$\quad$ Local Disease & \\
Locally Advanced Disease &
\end{tabular}

The mean HADS-A and HADS-D scores of the patients were $8.85 \pm 6.53$ and $6.79 \pm 5.91$, respectively. The mean global quality of life score was $61.07 \pm 32.51$, fatigue score was $50.5 \pm 38.81$ and pain score was 
$24.38 \pm 29.5$. The vaginismus and anorgasmi scores $(3.32 \pm 1.72,3.94 \pm 2.48)$ were found higher than the other subscores of GRISS. Among all, $46.26 \%$ of the patients showed results above the cut-off for depression and $40.29 \%$ had high anxiety above the cut-off. The mean scores of HADS, EORTC-QLQ-C30 and GRISS of the patients were shown in Table 2 .

Table 2. The mean scores of HADS, EORTCQLQ-C30 and GRISS of the patients

\section{$\operatorname{mean} \pm$ SD}

\begin{tabular}{lc}
\hline HAD Anxiety score & $8.85 \pm 6.535$ \\
\hline HAD Depression score & $6.79 \pm 5.915$ \\
\hline Total HAD & $15.64 \pm 11.43$ \\
\hline Physical functioning & $65.84 \pm 24.95$ \\
\hline Role functioning & $72.28 \pm 33.08$ \\
\hline Cognitive functioning & $63.93 \pm 36.44$ \\
\hline Emotional functioning & $58.95 \pm 35.74$ \\
\hline Social functioning & $66.66 \pm 37.93$ \\
\hline Global quality of life & $61.07 \pm 32.51$ \\
\hline Fatigue & $50.5 \pm 38.81$ \\
\hline Pain & $24.38 \pm 29.05$ \\
\hline Nausea and vomiting & $21.64 \pm 34.93$ \\
\hline Dyspnea & $17.99 \pm 29.2$ \\
\hline Insomnia & $27.36 \pm 40.17$ \\
\hline Appetite loss & $22.88 \pm 36.33$ \\
\hline Constipation & $14.42 \pm 29.14$ \\
\hline Diarrhea & $6.96 \pm 24.29$ \\
\hline Financial problems & $29.84 \pm 41.49$ \\
\hline Avoidance & $2.4 \pm 2.12$ \\
\hline Frequence & $2.78 \pm 1.13$ \\
\hline Vaginismus & $3.32 \pm 1.72$ \\
\hline Satisfaction & $2.04 \pm 1.7$ \\
\hline Communication & $2.17 \pm 1.81$ \\
\hline Anorgasmi & $3.94 \pm 2.48$ \\
\hline Touch & $2.4 \pm 2.29$ \\
\hline HADS: Hospital Anxiety and Depression Scale \\
Eatisfaction & Inventory of Sexual \\
\hline on Treatment of Cancer Questionnaires Quality of Life- \\
\hline 30 & \\
\hline
\end{tabular}

The comparison of the EORTC-QLQ-C30, GRISS scores and anxiety levels of the patients were shown in Table 3 and 4 . It was determined that physical, role, cognitive, emotional and social functioning and global

Table 3. Comparison of the EORTC QLQ-C30 scores and anxiety levels of the patients

\begin{tabular}{rll}
\hline Physical functioning & & \\
anxiety $\geq 10$ & $57.38 \pm 26.17$ & $\mathbf{0 . 0 2 1}$ \\
anxiety $<10$ & $71.5 \pm 22.68$ & \\
\hline
\end{tabular}

\begin{tabular}{|c|c|c|}
\hline $\begin{array}{l}\text { Role functioning } \\
\qquad \begin{array}{l}\text { anxiety } \geq 10 \\
\text { anxiety }<10\end{array}\end{array}$ & $\begin{array}{l}59.5 \pm 35.32 \\
80.9 \pm 28.83\end{array}$ & 0.008 \\
\hline $\begin{array}{c}\text { Cognitive functioning } \\
\text { anxiety } \geq 10 \\
\text { anxiety }<10\end{array}$ & $\begin{array}{l}52.47 \pm 35.93 \\
71.6 \pm 35.14\end{array}$ & 0.03 \\
\hline $\begin{array}{c}\text { Emotional functioning } \\
\text { anxiety } \geq 10 \\
\text { anxiety }<10\end{array}$ & $\begin{array}{l}36.11 \pm 31.9 \\
74.37 \pm 29.6\end{array}$ & 0.001 \\
\hline $\begin{array}{l}\text { Social functioning } \\
\text { anxiety } \geq 10 \\
\text { anxiety }<10\end{array}$ & $\begin{array}{l}58.64 \pm 39.5 \\
72.08 \pm 36.27\end{array}$ & 0.156 \\
\hline $\begin{array}{c}\text { Global quality of life } \\
\text { anxiety } \geq 10 \\
\text { anxiety }<10\end{array}$ & $\begin{array}{l}44.14 \pm 32.26 \\
72.49 \pm 27.62\end{array}$ & 0.001 \\
\hline $\begin{array}{l}\text { anxiety } \geq 10 \\
\text { anxiety }<10\end{array}$ & $\begin{array}{l}26.54 \pm 27.4 \\
22.9 \pm 30.35\end{array}$ & 0.62 \\
\hline $\begin{array}{c}\text { Nausea and vomiting } \\
\text { anxiety } \geq 10 \\
\text { anxiety }<10 \\
\end{array}$ & $\begin{array}{l}20.9 \pm 34.46 \\
22.08 \pm 35.67\end{array}$ & 0.9 \\
\hline $\begin{array}{l}\text { Dyspnea } \\
\text { anxiety } \geq 10 \\
\text { anxiety }<10 \\
\end{array}$ & $\begin{array}{l}24.69 \pm 33.13 \\
13.33 \pm 25.64\end{array}$ & 0.119 \\
\hline $\begin{array}{l}\text { Insomnia } \\
\quad \text { anxiety } \geq 10 \\
\text { anxiety }<10\end{array}$ & $\begin{array}{l}41.97 \pm 44.9 \\
17.5 \pm 33.75\end{array}$ & 0.013 \\
\hline $\begin{array}{r}\text { Appetite loss } \\
\quad \text { anxiety } \geq 10 \\
\text { anxiety }<10 \\
\end{array}$ & $\begin{array}{l}24.68 \pm 36.5 \\
21.66 \pm 36.63\end{array}$ & 0.741 \\
\hline $\begin{array}{l}\text { Constipation } \\
\quad \text { anxiety } \geq 10 \\
\text { anxiety }<10\end{array}$ & $\begin{array}{l}11.1 \pm 24.45 \\
16.66 \pm 32.02\end{array}$ & 0.448 \\
\hline $\begin{array}{r}\text { Diarrhea } \\
\quad \begin{array}{l}\text { anxiety } \geq 10 \\
\text { anxiety }<10\end{array}\end{array}$ & $\begin{array}{l}8.64 \pm 27.09 \\
5.83 \pm 22.5\end{array}$ & 0.64 \\
\hline $\begin{array}{r}\text { Financial problems } \\
\text { anxiety } \geq 10 \\
\text { anxiety }<10\end{array}$ & $\begin{array}{l}39.5 \pm 44.37 \\
23.3 \pm 38.63\end{array}$ & 0.118 \\
\hline
\end{tabular}

EORTC- QoL-C30: European Organization for Research on Treatment of Cancer Questionnaires Quality of Life-C30

QoL subscores were low in the patients whose anxiety levels were high whereas pain, dyspnea, insomnia, appetite loss, diarrhea subscores were higher in the patients who has high anxiety levels. When we analyzed the results in terms of EORTC-QLQ-C30, we found statistical significance in the physical, role, cognitive and emotional functioning, global QoL and insomnia subscores of the patients (Table 3). All the GRISS subscores were found higher in the patients whose anxiety levels were high. However, statistical significance was found only in the communication, satisfaction, touch and anorgasmi subscores (Table 4).

Adress for correspondence: Doç. Dr. Ahmet Alacacıoğlu, Izmir Katip Celebi University, Ataturk Training and Research Hospital, Medical Oncology, Izmir, Turkey IZMMiR - Türkiye e-mali: dralaca2000@yahoo.com]

Available at www.actaoncologicaturcica.com

Copyright @Ankara Onkoloji Hastanesi 
Table 4. Comparison of the GRISS scores and anxiety levels of the patients

Patient p

\begin{tabular}{clc}
\hline $\begin{array}{c}\text { Frequency } \\
\text { anxiety } \geq 10\end{array}$ & $3.1 \pm 0.9$ & 0.061 \\
anxiety $<10$ & $2.57 \pm 1.19$ & \\
\hline $\begin{array}{c}\text { Communication } \\
\text { anxiety } \geq 10\end{array}$ & $2.7 \pm 1.75$ & $\mathbf{0 . 0 2 6}$ \\
anxiety $<10$ & $1.7 \pm 1.75$ & \\
\hline $\begin{array}{c}\text { Satisfaction } \\
\text { anxiety } \geq 10\end{array}$ & $2.7 \pm 1.9$ & $\mathbf{0 . 0 0 8}$ \\
anxiety $<10$ & $1.6 \pm 1.3$ & \\
\hline Avoidance & & \\
anxiety $\geq 10$ & $2.93 \pm 2.13$ & 0.094 \\
anxiety $<10$ & $2.05 \pm 2.06$ & \\
\hline Touch & & \\
anxiety $\geq 10$ & $3.22 \pm 2.69$ & $\mathbf{0 . 0 1 4}$ \\
anxiety $<10$ & $1.84 \pm 1.82$ & \\
\hline Vaginismus & & \\
anxiety $\geq 10$ & $3.31 \pm 1.64$ & 0.963 \\
anxiety $<10$ & $3.3 \pm 1.78$ & \\
\hline Anorgasmi \\
anxiety $\geq 10$ & $4.72 \pm 2.26$ & $\mathbf{0 . 0 3 3}$ \\
anxiety $<10$ & $3.41 \pm 2.5$ & \\
\hline
\end{tabular}

GRISS: Golombok-Rust Inventory of Sexual Satisfaction

The comparison of the EORTC-QLQC30, GRISS scores and depression levels of the patients were shown in Table 5 and 6 . In the patients whose depression scores were high, all the functioning scales, except physical functioning scale, and global quality of life subscores of EORTC-QLQ-C30 were found statistically significantly low. All the symptom subscores were found high in the patients who had high depression levels. The result was also similar with respect to anxiety level, all the subscores of GRISS were determined higher in the patients whose depression levels were high. Statistically significant difference was observed only in pain, dyspnea, insomnia, appetite loss and financial problems (Table 5). All the GRISS subscores were higher in the patients who had high depression level. But statistical significance was found only in communication, satisfaction, touch and anorgasmi subscores (Table 6).

Table 5. Comparison of the EORTC-QLQ-C30 scores and depression levels of the patients

\begin{tabular}{ll}
\hline & Patient p \\
\hline Physical functioning & \\
\hline
\end{tabular}

\begin{tabular}{|c|c|c|}
\hline $\begin{array}{l}\text { depression } \geq 7 \\
\text { depression }<7\end{array}$ & $\begin{array}{l}60.77 \pm 24.56 \\
70.2 \pm 24.8\end{array}$ & 0.124 \\
\hline $\begin{array}{l}\text { Role functioning } \\
\text { depression } \geq 7 \\
\text { depression }<7\end{array}$ & $\begin{array}{l}62.37 \pm 35.87 \\
80.82 \pm 28.27\end{array}$ & 0.022 \\
\hline $\begin{array}{r}\text { Cognitive functioning } \\
\text { depression } \geq 7 \\
\text { depression }<7\end{array}$ & $\begin{array}{l}45.43 \pm 35.9 \\
79.85 \pm 28.8\end{array}$ & 0.001 \\
\hline $\begin{array}{c}\text { Emotional functioning } \\
\text { depression } \geq 7 \\
\text { depression }<7\end{array}$ & $\begin{array}{l}39.25 \pm 33.27 \\
75.9 \pm 28.64\end{array}$ & 0.001 \\
\hline $\begin{array}{l}\text { Social functioning } \\
\text { depression } \geq 7 \\
\text { depression }<7\end{array}$ & $\begin{array}{l}53.2 \pm 40 \\
78.24 \pm 32.31\end{array}$ & 0.006 \\
\hline $\begin{array}{c}\text { Global quality of life } \\
\text { depression } \geq 7 \\
\text { depression }<7\end{array}$ & $\begin{array}{l}47.04 \pm 30.7 \\
73.15 \pm 29.28\end{array}$ & 0.001 \\
\hline $\begin{array}{ll}\text { Pain } & \\
& \begin{array}{l}\text { depression } \geq 7 \\
\text { depression }<7\end{array} \\
\end{array}$ & $\begin{array}{l}34.9 \pm 33.14 \\
15.28 \pm 21.59\end{array}$ & 0.005 \\
\hline $\begin{array}{r}\text { Nausea and vomiting } \\
\text { depression } \geq 7 \\
\text { depression }<7\end{array}$ & $\begin{array}{l}26.88 \pm 39.35 \\
17.12 \pm 30.46 \\
\end{array}$ & 0.257 \\
\hline $\begin{array}{l}\text { Dyspnea } \\
\text { depression } \geq 7 \\
\text { depression }<7\end{array}$ & $\begin{array}{l}28.49 \pm 35 \\
8.79 \pm 19.3 \\
\end{array}$ & 0.005 \\
\hline $\begin{array}{l}\text { Insomnia } \\
\text { depression } \geq 7 \\
\text { depression }<7 \\
\end{array}$ & $\begin{array}{l}40.86 \pm 46.9 \\
15.73 \pm 29.26\end{array}$ & 0.01 \\
\hline $\begin{array}{l}\text { Appetite loss } \\
\text { depression } \geq 7 \\
\text { depression }<7\end{array}$ & $\begin{array}{l}33.32 \pm 43.03 \\
13.88 \pm 26.87 \\
\end{array}$ & 0.028 \\
\hline $\begin{array}{l}\text { Constipation } \\
\text { depression } \geq 7 \\
\text { depression }<7\end{array}$ & $\begin{array}{l}17.2 \pm 32.06 \\
12.03 \pm 26.6\end{array}$ & 0.473 \\
\hline $\begin{array}{l}\text { Diarrhea } \\
\text { depression } \geq 7 \\
\text { depression }<7\end{array}$ & $\begin{array}{l}28.49 \pm 35 \\
8.79 \pm 19.3 \\
\end{array}$ & 0.862 \\
\hline $\begin{array}{c}\text { Financial problems } \\
\text { depression } \geq 7 \\
\text { depression }<7\end{array}$ & $\begin{array}{l}40.86 \pm 46.11 \\
20.36 \pm 34.98\end{array}$ & 0.043 \\
\hline
\end{tabular}

EORTC- QoL-C30: European Organization for Research on Treatment of Cancer Questionnaires Quality of Life-C30

Table 6. Comparison of the GRISS scores and depression levels of the patients

\begin{tabular}{clc}
\hline & Patient & P \\
\hline Frequency & & \\
depression $\geq 7$ & $2.9 \pm 1.06$ & 0.170 \\
depression $<7$ & $2.6 \pm 1.18$ & \\
\hline Communication & & \\
depression $\geq 7$ & $2.7 \pm 1.69$ & $\mathbf{0 . 0 2 5}$ \\
depression $<7$ & $1.7 \pm 1.8$ & \\
\hline Satisfaction & & \\
depression $\geq 7$ & $2.64 \pm 1.92$ & $\mathbf{0 . 0 0 6}$ \\
depression $<7$ & $1.53 \pm 1.3$ & \\
\hline
\end{tabular}

Adress for correspondence: Doç. Dr. Ahmet Alacacıoğlu, Izmir Katip Celebi University, Ataturk Training and Research Hospital, Medical Oncology, Izmir, Turkey İZMíR - Türkiye 


\begin{tabular}{ccc}
\hline Avoidance & & \\
depression $\geq 7$ & $2.72 \pm 2.11$ & 0.265 \\
depression $<7$ & $2.13 \pm 2.12$ & \\
\hline Touch & & \\
depression $\geq 7$ & $3.15 \pm 2.55$ & $\mathbf{0 . 0 1 1}$ \\
depression $<7$ & $1.75 \pm 1.85$ & \\
\hline Vaginismus & & \\
depression $\geq 7$ & $3.71 \pm 1.81$ & 0.081 \\
depression $<7$ & $2.9 \pm 1.58$ & \\
\hline Anorgasmi & & \\
depression $\geq 7$ & $4.69 \pm 2.44$ & $\mathbf{0 . 0 2}$ \\
depression $<7$ & $3.29 \pm 2.35$ & \\
\hline
\end{tabular}

GRISS: Golombok-Rust Inventory of Sexual

Satisfaction

\section{Discussion}

In $\mathrm{BC}$, patients may experience physical loss, emotional distress, destruction in family, work and social roles. It may also cause uncertainty about changes in a woman's body image and treatment options. Besides, these intense and long-time treatments and its adverse effects could lead to psychosocial and sexual problems and could result in reduced quality of life for breast cancer patients (27). As cancer is a chronic disease, the quality of life can be affected in various dimensions including the physical, psychological, social, functional and sexual (28). In this study, we evaluated depression, anxiety, quality of life and sexual satisfaction of the premenopausal breast cancer patients treated with adjuvant tamoxifen.

In women with early breast cancer, the prevalence of depression, anxiety or both in the year after diagnosis is about twice that of the general female population. We found that $46.26 \%$ of the patients showed results above the cut-off level for depression and $40.29 \%$ had high anxiety levels. In a study conducted by Pandey et al. (2), depression range was found as low as $16.2 \%$. Lim et al. reported that nearly $60 \%$ of cancer patients may experience feelings of anxiety and depression (29) whereas Thewes et al found that $32 \%$ of the patients showed results above the cut-off level for depression and $14 \%$ had high anxiety levels (30).

In our study we also examined the relation between depression and anxiety level, and quality of life. We found that the women with high anxiety levels had low physical, role, cognitive, emotional and social functioning and global quality of life subscores. In the patients whose depression scores were high, all the functioning scales, except physical functioning scale, and global quality of life subscores of EORTC-QLQ-C30 were found statistically significantly low. All the symptom subscores were found high in the patients who had high depression levels. Statistical significance was determined only in pain, dyspnea, insomnia, appetite loss and financial problems.

Tamoxifen improves survival for premenopausal women diagnosed with earlystage breast cancer. However, it also have many unpleasant side-effects including menopausal hot flashes, other vasomotor symptoms, cognitive problems, loss of bonemineral density, changes in body image and sexual function, vaginal dryness and altered plans for child-bearing (31). The drug has estrogen agonist effect and theoretically, treatment with tamoxifen could result in vaginal atrophy and problems with desire (32). But it is unclear that whether tamoxifen has a favorable or unfavorable effect on sexual functioning (33).

Sexual satisfaction of the patients who were treated with adjuvant tamoxifen according to depression and anxiety levels was also analyzed in this study. All the patients who had high depression and anxiety levels had higher subscores of GRISS. Statistical significance was in communication, satisfaction, touch and anorgasmi subscores of the patients who had higher depression and anxiety levels. Schover et al. stated that the women who had received adjuvant chemotherapy had higher incidence of sexual dysfunction (vaginal dryness, dyspareunia and decreased libido) than the women who were treated with either adjuvant tamoxifen or no additional systemic therapy. It was also determined that the incidence of sexual dysfunction in women treated with tamoxifen was similar with the patients who did not receive any systemic therapy (34). In the study of McCaughan et al., it is found that the women who were treated with hormonal therapy did not experience significantly different levels of sexual dysfunction than the women who were not treated with hormonal therapy (35). Similarly, Ganz et al. examined the relation between tamoxifen usage and sexual functioning in breast cancer survivors and they revealed no difference in sexual functioning between women treated with or 
without tamoxifen (36). In contrast with these studies, Joanne et al observed that women treated with tamoxifen could experience symptoms of sexual dysfunction (19).

Limited number of the patients and different follow-up intervals of the patients were the major limitations of our study. The other limitation was we didn't know the anxiety and depression scores of the patients before using tamoxifen. However, detailed analysis of the effects of adjuvant tamoxifen treatment on our premenopausal breast cancer patients gave us important clues about how to identify these problems and manage them before they were apparent. In conclusion, breast cancer and its long-term adjuvant tamoxifen treatment affects not only the patients' clinical status but also their psychosocial and psychosexual aspects. Thus, being aware of these aspects and taking precautions may increase the quality of the breast cancer patients.

\section{Conflict of Interest: None}

\section{References}

1. Breast cancer resource center facts and figures, 2001. American Cancer Society Web site. Avaliable at http://www.cancer .org.Accessed July 31, 2001

2. Pandey M, Sarita GP, Devi N, et al. Distress, anxiety and depression in cancer patients undergoing chemotherapy. World J Surg Oncol 2006;4:68

3. Brem S, Kumar NB. Management of treatmentrelated symptoms in patients with breast cancer:current strategies and future directions. Clin J Oncol Nurs 2011;15:63-71

4. Epplein M, Zheng Y, Zheng W et al. Quality of life after breast cancer diagnosis and survival . J Clin Oncol 2011;29;406-12

5. Derogatis LR, Morrow GR, Fetting J. The prevelance of psychiatric disorder among cancer patients. JAMA 1983;297:751-5

6. Trask P. Assessment of depression in cancer patients. Journal of the National Cancer Institute: Monographs 2004;32:80-92

7. Stark D, Kiely M, Smith A, Velikova G, House A, Selby P. Anxiety disorders in cancer patients: Their nature, associations and relation to quality of life. Journal of Clinical Oncology 2002;14:3137-48

8. Pumo V, Milone G, Iacono M, et al. Psychological and sexual disorders in long-term breast cancer survivors. Cancer Manag Res 2012;4:61-5

9. Badger T, Sergin C, Dorros SM, Meek P, Lopez AM. Depression and anxiety in women with breast cancer and their partners. Nurs Res 2007;56:44-53

10. Avis NE, Crawford S, Manuel J. Quality of life among younger women with breast cancer. J Clin Oncol 2005;23:3322-30
11. Wenzel LB, Fairclough DL, Brady MJ, et al. Agerelated differences in the quality of life of breast carcinoma patients after treatment. Cancer 1999;86:1768-74

12. Schou I, Ekeberg O, Ruland CM, Sandvik L, Karesen R. Pessimism as a predictor of emotional morbidity one year following breast cancer surgery. PsychoOncology 2004;13:309-20

13. Early Breast Cancer Trialists Group Ovarian ablation in early breast cancer: overview of the randomised trials. Lancet 1996;348:1189-96

14. Early Breast Cancer Trialists Group. Tamoxifen for early breast cancer: an overview of the randomised trials. Lancet 1998;351:1451-67

15. Jonat W, Kaufmann M, Sauerbrei R, et al. For the Zoladex Early Breast Cancer Collaborative Research Assosiationgroup. Goserelin versus cyclophosphamide and fluorouracil as adjuvant therapy in premenopausal patients with node-pozitive breast cancer. J Clin Oncol 2002;20:4628-35

16. Boccardo F, Bruzzi A, Rubagtti G, et al. Estrogenlike action of tamoxifen on vaginal epithelium in breast cancer patients. Oncology 1981;38:281-5

17. Ferrazzi E, Cartei G, Mattarazzo R, et al: Oestrogenlike effect of tamoxifen on vaginal epithelium. BMJ 1977;1:1351-2

18. Thors CL, Broeckel JA, Jacobsen PB. Sexual functioning in brest cancer survivors. Cancer Control 2001;8:442-8

19. Mortimer JE, Boucher, L, Baty J, Knapp DL, Ryan E, Rowland JH. Effect of Tamoxifen on Sexual Functioning in Patients With Breast Cancer. J Clin Oncol 1999;17:1488-92

20. Zigmond AS, Snaith RP. The hospital anxiety and depression scale. Acta Psychiatr Scand 1983;67:36170

21. Aydemir Ö. Hastane Anksiyete ve Depresyon Ölçeği Türkçe formunun geçerlilik ve güvenilirlik çalışması. Türk Psikiyatri Dergisi 1997;8:280-7

22. Rust J, Golombok S. The GRISS: a psychometric instrument for the assessment of sexual dysfunc-tion. Arch Sex Behav 1986;15:157-65

23. Tuğrul C, Öztan N, Kabakçı E. Golombok-Rust Cinsel Doyum Ölçeği'nin standardizasyon çalışması. Türk Psikiyatri Dergisi 1993;4:83-8

24. Aaronson NK, Ahmedzai S, Bergman B, et al. The European Organization for Research and Treatment of Cancer QLQ-c30: a quality of life instrument for use in international clinical trials in oncology. Journal of the National Cancer Institute 1993;85:365-76

25. Fayers P, Aaronson N, Bjordal K, Groenvold M, Curran D, Bottomley A. EORTC QLQ-C30 Scoring Manual, In third edition ed, 2001

26. Beser N, Öz F. Kemoterapi alan lenfomalı hastaların anksiyete-depresyon düzeyleri ve yaşam kalitesi. C.Ü. Hemşirelik Yüksekokulu Dergisi 2003;7:47-58

27. Palson M-BE, Norberg A. Breast cancer experiences of nursing care with the focus on emotional support: The implication of a nursing intervention. Journal of Advanced Nursing 1995;21:277-85

28. Henson HK. Breast Cancer and Sexuality. Sexuality and Disability 2002;20:261-75

29. Lim CC, Devi MK, Ang E. Anxiety in women with breast cancer undergoing treatment: a systematic review. Int J Evid Based Healthc 2011;9:215-35 
30. Thewes B, Meiser B, Duric VM, et al. What survival benefits do premenopausal patients with early breast cancer need to make endocrine therapy worthwhile? Lancet Oncol 2005;6:581-8
31. Fallowfield LJ, Leaity S, Howell A, et al. Assessment of quality of life in women undergoing hormonal therapy for breast cancer: validation of an endocrine symptom subscale for the FACT B. Breast Cancer Res Treat 1999;55:189-99

32. Anllo LM. Sexual life after breast cancer. J Sex Marital Ther 2000;26:241-8

33. Simes R, Coates A. Patient preferences for adjuvant chemotherapy of early breast cancer: how much benefit is needed? Monogr Natl Cancer Instit 2001;30:146-52

34. Schover LR, Yetman RJ, Tuason LJ, et al. Partial mastectomy and breast reconstruction:Acomparison of their effects on psychosocial adjustment, body image, and sexuality. Cancer 1995;75:54-64

35. Young-McCaughan S. Sexual functioning in women with breast cancer after treatment with adjuvant therapy. Cancer Nurs 1996;19:308-19

36. Ganz PA, Rowland JH, Meyerowitz BE, et al. Impact of different adjuvant therapy stragies on quality of life in breast cancer survivors. Recent Results Cancer Res 1998;152:396-411 